\title{
HasanuddinLawReview
}

\section{The Necessity of ASEAN Competition Law: Rethinking}

\author{
Udin Silalahi', Dian Parluhutan² \\ ${ }^{1}$ Faculty of Law, Universitas Pelita Harapan, Karawaci, Indonesia. E-mail: udin.silalahi@uph.edu \\ 2 Faculty of Law, Freie University of Berlin, Germany. E-mail: dian.parluhutan@fu-berlin.de
}

\section{ARTICLE INFO}

Keywords:

AEC; Competition

Authority; Competition

Law

How to cite:

Silalahi, U., E Parluhutan,

D. (2017). The Necessity of

ASEAN Competition Law:

Rethinking. Hasanuddin

Law Review, 3(3): 218-230

DOI:

10.20956/halrev.v3i3.1165

\begin{abstract}
As outlined in the AEC Blueprint, all ASEAN member states (AMSs) will endeavour to introduce competition policy by 2015. At present 7 (seven) AMSs, namely: Indonesia, Singapore, Malaysia, Thailand, Vietnam, Philippines, Myanmar have the national competition laws to supervise anti-competitive conduct in the domestic market. But the question is what if happened unfair competition between ASEAN member states, due to the agreement or businesses activities by business actors that harm competition? ASEAN has an ASEAN Regional Guidelines on Competition Policy (ARGCP) that developed by ASEAN Experts Group on Competition (AEGC) as framework for member states to develop its own competition law or policy and as a guideline in measuring that directly affect the behaviour of enterprises and the structure of industry and markets. Regional Guideline is just to help AMSs in increasing of awareness of important policy, not to sustain the competition among ASEAN member countries. Until now there is no ASEAN Competition Law and Institution to oversee competition among ASEAN member countries. In this era, ASEAN economic integration it is a certainty that anti-competitive among AMSs will happen.
\end{abstract}

Copyright $\odot 2017$ HALREV. All rights reserved.

\section{Introduction}

In the year of 2015, the governmental leaders of ASEAN Association of South East Asian Nations) Countries have introduced the ASEAN Economic Community (AEC) Blueprint 2025 as well as the ASEAN Community Vision 2025. Accordingly, the AEC Blueprint 2025 founded upon five interrelated and mutually reinforcing pillars: First, a highly integrated and cohesive economy. Second, competitive, innovative, and dynamic ASEAN. Third, enhanced connectivity and sectoral cooperation. Fourth, a resilient, inclusive, people-oriented, and people-centered ASEAN. Fifth, a global ASEAN. ${ }^{1}$ Previously, by virtue of the ASEAN Concord II declared in Bali on 2003 the ASEAN Countries have agreed to establish the ASEAN Economic Community ("AEC") by 2015 which will not only transform ASEAN into a region with free movement of goods,

1 ASEAN Secretariat. (2015). ASEAN Economic Community Blueprint 2025. Jakarta: ASEAN Secretriat, p. 1 
services, investment and skilled labour, and a freer flow of capital, but also to a highly competitive region that is fully integrated with the global economy. ${ }^{2}$ Furthermore, the ASEAN Leaders through the Declaration on the ASEAN Economic Community Blueprint (AEC Blueprint) in Singapore in November 2007, agreed on joint statement as follows:

“... the AEC Blueprint which each ASEAN Member Country shall abide by and implement the AEC by 2015. The AEC Blueprint will transform ASEAN into a single market and production base, a highly competitive economic region, a region of equitable economic development, and a region fully integrated into the global economy..."

The provision of Article 1 number 5 of ASEAN Charter does not regulate only the ASEAN single market but also shall set the culture of competition. It can be seen from the words "...highly competitive an economically integrated with...".3 The word "highly competitive" asserts that in carrying out the ASEAN single market must be created the culture of competition. The cultural competition is actually already existing in every behavior of business actors in conducting its business in each country, because every business actor in doing business has the goal to become the bigger than their competitors, both in the domestic market and in the regional market in the context of the ASEAN. 4

Equally important, Sivalingam is of opinion that there are three principal factors catalyzing the economic integration under the AEC framework. Firstly, the processes towards a market economy due to the deeper integration of ASEAN's economies with the global economies and domestic upheavals. Secondly, the proliferation of Multi National Enterprises (MNEs), which engage in generating goods and service products and at the same time penetrating the South East Asian markets through their products..$^{5}$ Thirdly, institutional consequences of the Membership of ASEAN Countries in the WTO (World Trade Organization). ${ }^{6}$ Currently, 8 (eight) of the ASEAN Countries

2 Through the AEC the currently 10 (ten) ASEAN Member States determine themselves to achieve the following core objectives gradually, as follows: First, the single market and production base. Second, the highly competitive economic region. Third, the region of equitable economic development. Fourth, the region fully integrated into the global and other regional economies. See further ASEAN Economic Community Blueprint. (2008). Jakarta: ASEAN Secretariat

3 See Article 1 number 5 of ASEAN Charter.

4 Silalahi, U. (2012). "Accelerating the Development of ASEAN Competition Culture," Law Review XII(2): 241-254.

5 According to the Organization for Economic Co-operation and Development (OECD), Multinational Enterprises (MNEs) is defined as "...companies or other entities established in more than one country and so linked that they may co-ordinate their operations in various ways. While one or more of these entities may be able to exercise a significant influence over the activities of others, their degree of autonomy within the enterprise may vary widely from one multinational enterprise to another. Ownership may be private, state or mixed." In the ASEAN, DBS Group, Sembcorp, Petronas, and Temasek Ltd. are prominent MNEs, engaging in the financial service, energy-maritime, petrol-energy, and telecommunication service sectors. See: OECD Secretariat. (2008). OECD Guidelines for Multinational Enterprises. Paris: OECD Secretariat, p.12

6 The World Trade Organization (WTO) is "the only international organization dealing with the global rules of trade between nations. Its main function is to ensure that trade flows as smoothly, predictably and freely as possible." Further, the WTO is a global forum for the multilateral trading system consisting of "agreements, negotiated and signed by a large majority of the world's trading nations, and ratified in their parliaments. These agreements are the legal ground-rules for international commerce. Essentially, they are contracts, guaranteeing member countries important trade rights. They also bind governments to keep their trade policies within agreed limits to everybody's benefit. The agreements were negotiated and signed by governments. But their purpose is to help producers of goods and services, exporters, and importers conduct their business." Available online at: https://www.wto.org/english/thewto_e/whatis_e/inbrief_e/inbr00_e.htm, accessed on March 12, 2016. 
are the WTO's Members, which are: Indonesia, Singapore, Thailand, the Philippines, Brunei, Malaysia, Cambodia, and Myanmar. The other ASEAN Countries, Laos and Vietnam, are negotiating the WTO Membership. ${ }^{7}$

Principally, the ASEAN ongoing economic integration processes could be deemed as regional trade agreements (RTAs) phenomena subject to the WTO (World Trade Organization) regional integration regulatory framework. ${ }^{8}$ Hence, according to the World Bank, there have been strong interlinks between regional trade arrangement, such as economic integration and effective implementation of competition rules. ${ }^{9}$ According to Fox in the World Bank report, there have been strong interconnections between competition rules and trade liberalization processes. Arguably, it is widely believed that trade liberalizations, including an economic integration, prerequisite not only the removal of public trade barriers, such as quotas and custom duties. Further, these requires the removal of trade obstacles originating in private restraints, such as abuse of dominance, import cartels and vertical cartels. ${ }^{10}$

Consequently, the codification of regional competition law as well as its effective implementation are inevitably and necessarily important component in order to accelerate the attainment of ASEAN economic integration objectives pursuant to regulatory framework of the WTO. Regardless the beneficial impacts of the regional competition law, there have been juridical fragmentations as regards the implementation of common competition rules in ASEAN, such as divergent substantial rules and conflicting regulatory framework on law enforcement proceedings (mechanism) including the administrative/regulatory institution for implementing competition rules in ASEAN. Whereas there has been the ASEAN Regional Guidelines on Competition Policy ("ARGCP"), the competition law scholars point out reasonable criticism. For example, the ARGCP is not intended to be a full or binding legal instrument on competition policy for the ASEAN, but it merely serves as a general framework guide for the ASEAN Countries. In other words, the ARGCP serves merely as a "soft law", instead of a "hard law" on competition rules in ASEAN.11 Moreover, the ARGCP suffers from regional cooperation for implementing competition rules effectively in ASEAN.12 Because of since 31 December 2015 AEC already implemented, the unfair competition might be also occured between AMSs that done by business actors among AMSs. The question is which one of competition law will be implemented to protect and to sustain a fair competition law among AMSs? And who can implement that law? Until now, there is no ASEAN Competition Law to protect and to sustain a fair competition law in ASEAN region if the business actors conduct has an anti-competitive effect accross jurisdiction. So it is time to think again the necessity of ASEAN Competition law.

7 Available online at: $h t t p s: / / w w w . w t o . o r g / e n g l i s h / t h e w t o \_e / g l o s s a r y \_e / a s e a n \_e . h t m$, accessed on March 12, 2016.

8 Tongzon. (2004). "Free Trade Agreements: WTO and ASEAN Implications," The Copenhagen Journal of Asian Studies, (20): 95-98.

9 Geradin, D. (2004). Competition Law and Regional Economic Integration: An Analysis of the Southern Mediterranean Countries, Washington D.C: World Bank Working Paper 35, pp.95-98.

$10 \quad$ Ibid., p. 21

11 According to Abbott and Snidal "hard law" is an international institutional response based on binding commitments to create domestic compliance, whereas, "soft law" refers to commitments that are not formally binding. See: Abbott, K.W., \& Snidal, D. (2000). "Hard and Soft Law in International Governance." International Organization, 54(3), 421-456.

12 L. Huong-Ly. (2012). Regional Harmonization of Competition Law and Policy: An ASEAN Approach, Asian Journal of International Law Singapore, 2(2), p. 309 
Accordingly, this paper attempts to analyze and provide feasible solutions concerning the existing obstacles for the effective implementation of regional competition rules in the light of current endeavors to achieve economic integration goals in the ASEAN Countries.

\section{Necessity of and Convergence toward the Common Competition Law in ASEAN}

Historically, ASEAN economic integration is a result of the gradual economic regionalization processes, which are: Initially, ASEAN Free Trade Area (AFTA); ${ }^{13}$ Subsequently, ASEAN Investment Area (AIA); ${ }^{14}$ Afterward, ASEAN Framework Agreement on Services (AFAS); ${ }^{15}$ Eventually, ASEAN Economic Community (AEC). ${ }^{16}$

13 According to Myrna as regards the AFTA: "Established in 1992, the primary goal of AFTA is to increase ASEAN's competitive edge as the production base for the world market by decreasing intraregional tariff rates to $0-5$ percent through the Common Effective Preferential Tariff (CEPT) scheme within a 15-year period beginning 1993. The completion date was, however, progressively advanced. In 1995, it was moved from the original date of 2008 to 2003; and then in 1998, in response to the financial crisis, it was accelerated again to 2002 for the original AFTA signatories that include Brunei, Indonesia, Malaysia, Philippines, Singapore and Thailand or ASEAN-6. ...In pursuing the goal of establishing a single market and production base, the ASEAN Trade in Goods Agreement (ATIGA) was signed in 2009. ATIGA consolidates and streamlines all provisions in CEPT-AFTA and other protocols related to trade goods into one single legal instrument. It was entered into force in 2010 and supersedes CEPT-AFTA." Austria, M. (2012). Moving Towards an ASEAN Economic Community, Manila: CHED, p.144

14 According to Lawan Thanadsillapakul as to the AIA: "The Framework Agreement on the ASEAN Investment Area was signed on 8th October 1998 aiming at the establishment of the ASEAN Investment Area". This was a result of the decision made in the fifth ASEAN Summit, which called for the establishment of a regional investment arrangement to enhance the attractiveness of the region for direct investment flows. The establishment of AIA also pursues the objective of the Framework Agreement on Enhancing ASEAN Economic Co-operation or it is known as the Agreement on ASEAN Free Trade Area signed in Singapore on 28th January 1992. The objective of the Framework Agreement on AIA is to establish a competitive ASEAN Investment Area in order to "attract greater and sustainable levels of FDI into the region and to realize substantially increasing flows of FDI from both ASEAN and non-ASEAN sources by making ASEAN an attractive, competitive, open and liberal investment area". The agreement binds the member countries to "progressively reduce or eliminate investment regulations and conditions, which may impede investment flows and the operation of investment projects in ASEAN" and to ensure the implementation of AIA within the agreed time frame. The agreement on AIA provided three pillars of broad-based programs for encouraging investment in the ASEAN region: First, co-operation and facilitation. Second, promotion and awareness. Third, liberalization." See Thanadsillapakul, L. Framework Agreement on the ASEAN Investment Area (AIA), Thailand Law Forum, http://www.thailawforum.com/articles/lawanaia.html Accessed on 12.03.2016

15 According to the ASEAN Secretariat: "The services sector is a key driver of economic growth of ASEAN Member States (AMS), accounting for 40-70 percent of Gross Domestic Product (GDP). ASEAN's total trade in services more than doubled from USD 254 billion in 2005 to USD 590 billion in 2013. Recognizing the growing importance of services in the global economy, AMS developed and implemented the ASEAN Framework Agreement on Services (AFAS). AFAS was signed by the ASEAN Economic Ministers (AEM) on 15 December 1995 in Bangkok, Thailand. It aims to enhance cooperation to improve the efficiency, competitiveness and supply of services, and liberalize further the trade in services among AMS." Furthermore, "In its present form, an AFAS package consolidates all commitments made under the General Agreement on Trade in Services (GATS), previous AFAS packages, and improved or new commitments made for the current package. This means stakeholders have full information on the services commitments made by AMS in both the World Trade Organization (WTO) and AFAS by examining the latest AFAS package. Towards achieving greater regional services integration post-2015, AMS are reviewing and enhancing AFAS to take into account various developments such as the services elements in ASEAN's Free Trade Agreements (FTAs) with Dialogue Partners, the AEC Blueprint, and various other emerging regional architectures." ASEAN Secretariat, ASEAN Framework Agreement on Services Promoting Free Flow of Services through Progressive Liberalization. Source: http://www.asean.org/storage/images/2015/september/ Articles-on-AEC-2015/Edited\%20AFAS.pdf, accessed on 12.03.2016, p.1-2 
ASEAN Economic integration should be ruled and supported by regional rules that give undertaking law certainty in doing business amongs ASEAN countries including ASEAN competition law that protect and sustain a fair competition accross ASEAN countries. In the mean time, the ASEAN competition law scholars have generated the ASEAN Regional Guidelines on Competition Policy (ARGCP), which would serve as non-binding instrument to create a codified and unified regional competition law. ${ }^{17}$ ARGCP is merely drafted to serve as a "soft law", instead of a "hard law" on competition policy. ${ }^{18}$ Moreover, ARGCP contains substantial a shortcoming in the light of the competition law harmonization in the ASEAN, notably as regards to a regional cooperation.

ARGCP merely mandates an establishment of a regional platform of cooperation between Competition Authorities (CAs) in the ASEAN, whose functions are: exchanging experiences, identifying best practices, endeavoring to implement cooperative competition policy and legislative harmonization. Yet, this regional platform is not able to exercise any rule-making function and works on the basis of consensus-building. Accordingly, whenever the regional platform would have reached consensus on recommendations or "best practices", each CAs of the ASEAN Countries may decide whether and how to implement the recommendations by means of unilateral, bilateral or multilateral arrangement. ${ }^{19}$ Admittedly, the rationales behind this consensus-building approach would be the "conflicting interests" between the competition law and other national (economic) goals in the ASEAN Countries. ${ }^{20}$ Certainly, with reference to the convergence principle of competition rules as well as the recommended regional competition models in ASEAN, the existing regional competition guidelines (ARGCP) is inadequate to response the regional economic integration process and global economic progress. Thereby, taking into account current and future developments regionally and globally, the ASEAN Countries must start the "deep-convergence" of competition rules. ${ }^{21}$

According to Thanadsillapakul, the common competition law in ASEAN is profoundly essential for determining the successful outcome of economic integration processes in ASEAN. Arguably, there are several considerations thereof, as follows:

Firstly, the economic integration in ASEAN requires laws and institutions to support the implementation and elaboration of trade liberalization processes in ASEAN market. Accordingly, the interaction between government, consumers and producers brought consequence for strengthening a rules-based system. Thus, competition law is an essential instrument to institutionally strengthen economic integration processes; 22 Secondly, in the emerging market economy in ASEAN, monopolistic and restrictive

16 According to the ASEAN Secretariat concerning the ASEAN Economic Community (AEC): "The establishment of the ASEAN Economic Community (AEC) in 2015 is a major milestone in the regional economic integration agenda in ASEAN, offering opportunities in the form of a huge market of US\$2.6 trillion and over 622 million people. In 2014, AEC was collectively the third largest economy in Asia and the seventh largest in the world." Available online at: $h t t p: / / w w w . a s e a n . o r g / a s e a n-e c o n o m i c-c o m m u n i t y$, accessed on 12.03.2016

17 L. Huong-Ly, Op. Cit., p.1

18 K.W.Abbot and D. Snidal, Op Cit., p.421

19 L. Huong-Ly, Op Cit., p.310

20 D.P. Wood. (1992). The Impossible Dream: Real International Antitrust (The Impossible Dream: Real International Antitrust, University of Chicago Law School Chicago Unbound), p. 307

21 Geradin, D. Op Cit., pp. 69-70

22 Thanadsillapakul, L. (2004). The Harmonisation of ASEAN Competition Laws and Policy and Economic Integration, Bangkok. Available online at: http://www.jftc.go.jp/eacpf/04/thailand_lawan.pdf, accessed on 12.03.2016, p. $4-7$ 
business practices are undesirable because they cause price distortions and hamper an efficient allocation of resources. Hence, there is a need for market contestability ensuring equal access for incoming competitors and market powers and structures improvement as well as increasing consumer welfares in the ASEAN market; 23 Thirdly, the competition law in ASEAN would provide access to market for small and mediumsized undertakings (SMUs) to engage in regional business sectors, but they are, of course, subject to non-discriminatory principle of trade liberalization. ${ }^{24}$

In like manner, Stephan emphasizes the increasing necessity of common competition law in ASEAN. First, an increasing exposure to cross-border cartels, which control raw materials and key commodities of great importance to emerging economies. Second, weak enforcement of competition laws, that is to say, enforcements against competition law infringements are only currently undertaken by a small number of jurisdictions, with fines falling short of deterrence. Third, institutional constraints for enforcing competition laws, comprising: Inadequate assets in jurisdiction to enforce decisions; Fears of losing investment and jobs; Lobbying from foreign firms not to enforce laws. In addition, the Competition Authorities (CAs) in the ASEAN Countries have been also suffered from an institutional limitation, such as their ability to deal with regional infringements, whereas the boundaries of markets rarely coincide with the borders of legal jurisdictions. ${ }^{25}$

Nevertheless, taking into account current circumstances, the economic integration in ASEAN "only make processes, but not progress" ${ }^{26}$ Likewise, this proposition applies to the common competition law process in ASEAN. Interestingly, Hill and Menon believe that two reasons contribute to this circumstance. Firstly, the socio-political and economic diversities in ASEAN, which are greatly high compared to other regions. Secondly, while there have been prosperous regional economic developments and their beneficial advantages enjoyed by the ASEAN Countries, other Member Countries, such as Myanmar and Lao PDR have suffered from underperforming economic and business growth. ${ }^{27}$ Equally important, Myrna hypothesizes that the tempo of ASEAN economic integration has been largely slowed down by the decision making mechanism "ASEAN-Way", involving consensus, voluntarism, non-interference and informality. ${ }^{28}$ Besides, as regards the institutional framework of ASEAN economic integration, there is none of the "supra-national policy coordination to implement regional policies and regulations under a common authorized institution". Thus, Kreinin and Plummer contend that, unlike the European Union (EU), ASEAN will hardly to adopt a common external trade policy and to institute formal mechanisms for macroeconomic policy like a common currency. ${ }^{29}$ Put differently, there had been deficit of willingness of the ASEAN Countries to relinquish their national autonomies for pursuing harmonization of national policies and regulations, notably in the field of

23 Ibid.

24 Ibid.

25 A. Stephan. (2011). The Role of Competition Policy in Promoting the ASEAN Economic Community, ESRC Centre for Competition Policy University of East Anglia. Bali: ASEAN Competition Conference, p. 6-10

26 Smith, M.W., \& Martin, J.D. (2007). "Making Process, Not Progress: ASEAN and the Evolving East Asian Regional Order," International Security, 32 (1): pp. 148-9.

27 M.E. Kreinin and M.G. Plummer (Eds.). (2012). ASEAN Economic Integration: Driven by Markets, Bureaucrats, or Both? Oxford: The Oxford Handbook of International Commercial Policy, p.1-2.

28 Silalahi, U. (2017). "The Harmonization of Competition Laws towards the ASEAN Economic Integration," Journal of East Asia and International Law, 10 (1): 117-137.

29 M.E. Kreinin and M.G. Plummer (Eds.), Op Cit., p.1-2. 
competition matters. ${ }^{30}$ Myrna indicates that, ASEAN Countries has adopted an ambivalent position towards a formal institution process and prefer for easier, more flexible and less fundamental approach in the economic integration proceedings. ${ }^{31}$

Whereas the incorporation and enforcement of competition laws in the domestic legal systems of ASEAN Countries have been a relatively new phenomenon, there has been fragmentation of competition rules within the ASEAN Countries. ${ }^{32}$ Primarily, this refers to a notion that amongst the 10 (ten) Member Countries, nine of ASEAN Member Countries have already the national competition laws, namely: Indonesia, Singapore, Malaysia, Thailand, Vietnam, Philippines, Myanmar, Brunei Darrussalam, and Lao PDR. Cambodia is in the processes for enacting its competition law. ${ }^{33}$ Secondarily, this fragmented competition legislation denotes that the ASEAN domestic competition laws embody substantially different rules, for instance, how to regulate cross-border mergers and acquisitions. Eventually, this fragmentation of competition rules directly refers as well to conflicting regulatory framework concerning enforcement mechanism and administrative/regulatory bodies within the ASEAN Countries. ${ }^{34}$

Accordingly, these fragmented competition rules within the ASEAN Countries, could be best depicted in Table 1. As has been noted previously, several questions have emerged as to the effectiveness of current competition laws both to support and accelerate the attainment of ASEAN economic integration objectives, inter alia the ASEAN single market. ${ }^{35}$

To be sure, with regard the ASEAN economic integration and competition rules, the World Bank provides a proposal for initiating "convergence of the competition laws" within ASEAN Countries. By definition, convergence of competition rules is defined as the process whereby several nations or group of nations collectively decide to adopt identical, or at least compatible, rules and normative principles in one or several regulatory areas, notably competition aspect. ${ }^{36}$

30 Austria, M. (2003). Towards an ASEAN Economic Community. Manila: Business Focus of Manila Bulletin, p.1-3

31 Austria, M. (2004). Strategies towards an ASEAN Economic Community, CBERD Working Paper Series 2004-02. Manila, p.17

32 Silalahi, U. (2017)., Op.Cit., p. 124

33 D. Shiau and E. Chen. (2014). “ASEAN Developments in Merger Control," Journal of European Competition Law and Practice, 5(3): p.150.

34 Ibid.

35 Udin Silalahi (2017)., Op. Cit., p. 124.

36 Damien Geradin. (2004). p. 44-49 
Tabel 1. Competition Law Implementation in the ASEAN

\begin{tabular}{|c|c|c|c|}
\hline Country & Implementation & Year & Details \\
\hline Indonesia & Yes & 1999 & $\begin{array}{l}\text { Law No. } 5 \text { of } 1999 \text { Agency: Komisi Pengawas Persaingan Usaha } \\
\text { (KPPU, Commission for Supervision of Business Competition) }\end{array}$ \\
\hline Singapore & Yes & 2005 & $\begin{array}{l}\text { Competition Act Agency: Competition Commission of } \\
\text { Singapore (CCS) }\end{array}$ \\
\hline Malaysia & Yes & 2010 & $\begin{array}{l}\text { Competition Act } 2010 \text { Agency: Malaysia Competition } \\
\text { Commission (MyCC) Operational in March } 2011\end{array}$ \\
\hline Thailand & Yes & 1999 & $\begin{array}{l}\text { Trade Competition Act B.E.2542 (1999) Agency: Trade } \\
\text { Competition Commission }\end{array}$ \\
\hline Viet Nam & Yes & 2005 & $\begin{array}{l}\text { Competition Law No. 27/2004/QH11 Agencies: Viet Nam } \\
\text { Competition Authority (investigation) and Viet Nam } \\
\text { Competition Council (adjudication) }\end{array}$ \\
\hline Philippines & Yes & 2015 & $\begin{array}{l}\text { The Philippine Competition Act (the Competition Act), } \\
\text { promulgated on } 21 \text { July } 2015 .\end{array}$ \\
\hline Myanmar & Yes & 2015 & $\begin{array}{l}\text { ( } 2015 \text { Pyidaungsu } \\
\text { Hluttaw Law No 9) (the “Act”) take into } \\
\text { force on } 24 \text { February } 2015\end{array}$ \\
\hline Brunei & Yes & 2015 & The Competition Order 2015 - enacted in the mid - 2015. \\
\hline Lao PDR & Yes & 2015 & $\begin{array}{l}\text { The Law on Business Competition No. 60/NA, dated } 14 \text { July } \\
2015 \text {, take into force on } 24 \text { November } 2015\end{array}$ \\
\hline Cambodia & No & - & Draft law under consideration - Council of Ministers in 2012 \\
\hline
\end{tabular}

Tabel 2. Analysis of the Merger Control Provision

\begin{tabular}{|c|c|c|c|c|}
\hline States & Provision & Notification & Threshold & Sanctions/Remedies \\
\hline Indonesia & Art. 28-29 & $\begin{array}{l}\text { Pre-merger Notification } \\
\text { Voluntary Within } 30 \\
\text { days of merger }\end{array}$ & $\begin{array}{l}\text { Consolidated assets > } \\
\text { Rp. } 2.5 \text { trillion } \\
\text { Consolidated turnover } \\
\text { > Rp.5 trillion Banks: } \\
\text { Consolidated assets > } \\
\text { Rp.20 trillion }\end{array}$ & $\begin{array}{l}\text { Administrative: Revoke } \\
\text { merger Criminal: Min. } \\
\text { Rp. } 25 \text { bil, Max. Rp. } 100 \\
\text { bil or Max. } 6 \text { months } \\
\text { imprisonment }\end{array}$ \\
\hline Singapore & Sec. 34 & $\begin{array}{l}\text { Voluntary self- } \\
\text { assessment - for pre } \\
\text { \& post-merger }\end{array}$ & $\begin{array}{l}\text { Market share of } 40 \% \text { or } \\
\text { more or Market share } \\
\text { of } 20-40 \% \text { and post- } \\
\text { merger CR3 at } 70 \% \text { or } \\
\text { more }\end{array}$ & $\begin{array}{l}\text { Structural: Sale or } \\
\text { divestiture Behavioral: } \\
\text { Commitment to } \\
\text { specified conduct }\end{array}$ \\
\hline Malaysia & Sec. 4 & $\mathrm{~N} / \mathrm{A}$ & $\mathrm{N} / \mathrm{A}$ & $\mathrm{N} / \mathrm{A}$ \\
\hline Thailand & Sec. 26 & Compulsory & Not issued. & $\begin{array}{l}\text { No sanctions due to } \\
\text { absence of notification } \\
\text { thresholds }\end{array}$ \\
\hline Viet Nam & Art. 8 & Compulsory & Market share of $30-50 \%$ & $\begin{array}{l}\text { Financial penalty: } 1-3 \% \\
\text { of turnover }\end{array}$ \\
\hline
\end{tabular}

Source: Silalahi, U. (2017), p. 127

Pertaining convergence methods, Geradin recommends chiefly two methodological approaches for performing competition laws convergence. First, by means of regulatory "transplant" form, in which one of several involved nations decide to transpose in its domestic legal system one or several set(s) of competition rules from another nation. For example, the transposition of the acquis communautaire, namely the European competition laws, by the candidate countries acceding the European Union 
(EU). ${ }^{37}$ On the other hand, competition rules convergence is achievable by means of "approximation", in which concerned countries negotiate a common set of rules and then adjust their domestic competition regulations as to make them compatible with the common (regional) regulations. In the European economic integration proceedings, for instance, the approximation of competition rules is essentially concretized through negotiations and subsequently adoption of relevant "directives" (Rechtlinie) pursuant to Article 114 of the Treaty Functioning of European Union (TFEU). ${ }^{38}$

By virtue of "directive" all involved countries must achieve goals set out by this legislative act, whereas each participating country is free to devise its own laws on how to reach the devised goals. ${ }^{39}$ Also, in terms of degrees of intensity, convergence of competition rules could be classified into two types. Firstly, a "loose" convergence, whereby one or several countries decide to rely upon common normative principle in one regulatory aspect, yet the details on how to achieve compliance with the principles are given to national laws. For example, the OECD recommendation as to hard-core cartels. Secondly, a "deep" convergence, whereas the involved countries decide to harmonize divergent legal standards for facilitating free trade arrangements. 40

Equally important, Andrea-Florina exemplifies four available options for converging competition rules in the context of regional trade agreements (economic integration): ${ }^{4}$

Table 3. The Approximation of Compeition Policy

\begin{tabular}{|c|c|c|}
\hline Model & Key Characteristics & Examples \\
\hline \multirow[t]{3}{*}{ Centralized } & Regional authority & EU=European Union \\
\hline & Regional law & \\
\hline & Regional enforcement & \\
\hline \multirow[t]{3}{*}{ Partially centralized } & Regional authority & CARICOM=Caribbean Community \\
\hline & Regional law & \\
\hline & Domestic enforcement & \\
\hline \multirow[t]{3}{*}{ Partially decentralized } & No regional authority & MERCOSUR=Southern Cone Common Market \\
\hline & Regional law & ASEAN \\
\hline & Domestic enforcement & \\
\hline \multirow[t]{3}{*}{ Decentralized } & No regional authority & \\
\hline & No regional law & NAFTA=North American Free Trade \\
\hline & $\begin{array}{l}\text { Domestic law subject to } \\
\text { harmonization criteria }\end{array}$ & $\begin{array}{l}\text { Agreement } \\
\text { SACU }=\text { Southern African Customs Union }\end{array}$ \\
\hline
\end{tabular}

37 Ibid.

38 Ibid.

39 In the EU basic legislations, "directive" is a legislative act that sets out a goal that all EU countries must achieve. However, it is up to the individual countries to decide how. This was the case with the working time directive, which stipulates that too much overtime work is illegal. The directive sets out minimum rest periods and a maximum number of working hours, but it is up to each country to devise its own laws on how to implement this. Available from: http://europa.eu/eu-law/decision-making/legalacts/index_en.htm. See Udin Silalahi. (2017).p. 131.

40 Geradin, D. (2004), pp. 68-70

41 K. Dawar and P. Holmes, Competition Policy in J.P. Chauffour and J.C .Maur (Eds.) (2011). Preferential Trade Agreement. Policies for Development. Washington: The World Bank, p. 356-358. See also Fora Andreea-Florina Regional Trade Agreements and Competition Policy. Case Study: EU, ASEAN, and NAFTA (Annals of the University of Oradea, Economic Science Series, Volume 23 Issue 1:2014 ), p.91 
The ASEAN ongoing economic integration process, which is subject to the WTO regulatory framework, the establishment and effective implementation of regional competition law in the ASEAN Countries are of ultimately and necessarily important. There are several reasons thereof: First, the ASEAN economic integration compliance with WTO principles, prerequisite effective implementation of competition rules. Second, the regional competition laws are very important instrument to promote economic integration, by curbing market partitioning effects. Third, nowadays there have been strong interconnections between competition rules and trade liberalization processes. Arguably, it is widely believed that trade liberalizations, including an economic integration, prerequisite not only the removal of public trade barriers, such as quotas and custom duties. Further, these requires the removal of trade obstacles originating in private restraints, such as abuse of dominance, import cartels and vertical cartels. Fourth, competition law and economic integration goals share common aspirations, namely promoting an open market, providing a fair and equal business opportunities to all market participants, establishing transparency and fairness in the regulatory process, stimulating economic efficiency and maximizing consumer welfares.

\section{Conclusion}

The economic integration in ASEAN requires laws and institutions to support the implementation and elaboration of trade liberalization processes in ASEAN market. Accordingly, the interaction between government, consumers and producers brought consequence for strengthening a rules-based system. Thus, competition law is an essential instrument to institutionally strengthen economic integration processes. Thereby, taking into account current and future developments of regional economic integration both in the regional and global spheres, the ASEAN Countries must start the "deep-convergence" of competition rules. Hence, the ASEAN Countries shall initiate the partially centralized model of regional competition law, involving regional competition authority, regional competition law and domestic (national) law enforcement. Moreover, the ASEAN Countries could implement competition norms and principles through "decentralized" enforcement proceedings, providing certain margin of discretionary powers to each Competition Authority (CA). However, in order to ensure convergent (uniform) application of the regional competition rules, the ASEAN Competition Authority must periodically generate guidelines and elaborative notices (instruction).

The ASEAN countries should start sitting together to think again and discuss whether they need an ASEAN competition law or not and give AEGC the authority to rethink and to conduct in-depth studies of the common ASEAN Competition Law and ASEAN Antimonopoly Body and to share information with ASEAN Member Countries the necessity of the ASEAN Competition Laws to ensure and to protect the business competition among ASEAN countries. It is also necessary important to establish the regional competition network in South East Asian Countries, involving Competition Authorities, competition law scholars and practitioners, in order to safeguard the convergent implementation of competition rules in ASEAN. 


\section{References}

Abbott, K.W., \& Snidal, D. (2000). "Hard and Soft Law in International Governance." International Organization, 54(3), 421-456.

Andreea-Florina, F. (2014) Regional Trade Agreements and Competition Policy. Case Study: EU, ASEAN and NAFTA. Annals of the University of Oradea, Economic Science Series (23) (1): 86

ASEAN Secretariat. (2008). ASEAN Economic Community Blueprint. Jakarta: ASEAN Secretariat.

ASEAN Secretariat. (2015). ASEAN Economic Community Blueprint 2025: Progressive Liberalization, Jakarta: ASEAN Press.

Austria, M. (2003). Regional Economic Cooperation in East Asia, Manila: Center for Business and Economics Research and Development (CBERD) Working Series.

Austria, M. (2003). Towards an ASEAN Economic Community. Manila: Business Focus of Manila Bulletin.

Austria, M. (2012). Moving Towards an ASEAN Economic Community. East Asia International Quarterly, 29 (2).

Botta, M. (2011). The Role of Competition Policy in the Latin American Regional Integration: A Comparative Analysis of CARICOM; Andean Community and MERCOSUR. Paper on the IX Annual Conference of the Euro-Latin Study Network on Integration and Trade.

Briguglio L., (2012). Competition Law and Policy in the European Union -Some Lessons for South East Asia, Paper presented in the 37th FAEA Annual Conference ManilaPhilippines.

Dawar, K. and Holmes P. (2011). Competition Policy. In Preferential Trade Agreement. Policies for Development, Edited by J.P.Chauffour and J.C.Maur, Washington: The World Bank.

De Sousa, P.C. (2012). "Negative and Positive Integration in EU Economic Law: Between Strategic Denial and Cognitive Dissonance?" German Law Journal, 13(8).

Directorate General of ASEAN Cooperation, (2008). Ministry of Foreign Affairs Republic of Indonesia (2008)

Geradin, D. and Girgenson, I. (2012). The Counterfactual Method in EU Competition Law: The Cornerstone of the Effects-Based Approach. In Ten Years of Effect-Based Approach in EU Competition Law, Edited by Bourgeois and Waelbroeck, Bruylant

Geradin, Damien. (2004). Competition Law and Regional Economic Integration: An Analysis of the Southern Mediterranean Countries. Washington DC: World Bank Working Paper 35

Huong Ly, L. (2012). Regional Harmonization of Competition Law and Policy: An ASEAN Approach. Asian Journal of International Law, 2(2): 291 - 321.

Junaidi, A. (2011). Competition Authority in the ASEAN Member States Paper presented in the ASEAN Competition Conference, Bali, December 2011.

Kokkoris, I. (2013). Regional Economic Integration: The Role of Competition Law. Paper presented in the 9th Annual Conference in Hong Kong, 7-10 December 2013.

Kreinin, M.E. and Plummer, M.G. (Eds.). (2012). ASEAN Economic Integration: Driven by Markets, Bureaucrats, or Both? Oxford: The Oxford Handbook of International Commercial Policy.

Lee, C and Fukunaga, Y. (2014). ASEAN Regional Cooperation on Competition Policy Journal of Asian Economics (35): 77-91. 
Matsushita, M. (2004). Basic Principles of the WTO and the Role of Competition Policy. Washington University Global Studies Law Review, 3(2).

Ministry of Foreign Affairs Republic of Indonesia. (2008). ASEAN Selayang Pandang, Edisi 2008.

Monti, M. (2001). Antitrust in the US and Europe: A History of convergence, General Counsel Roundtable American Bar Association, Speech of the EC Competition Commissioner. Washington DC.

OECD. (2008). Roundtable on Cartel Jurisdiction Issues, Including the Effects Doctrine, Paris: OECD.

Qaqaya, Hassan. (2011). The Challenges in Introducing Competition Law and Policy in ASEAN Member States. Paper presented in the ASEAN Competition Conference, Bali, December 2011.

Razeen, S. (2013). ASEAN FTAs: State of Play and Outlook for ASEAN's Regional and Global Integration in Severino, Rudolfo, et.al, "The ASEAN Economic Community: A Work in Progress", Manila: Asian Development Bank (ADB).

Schmidt I., (2005). Wettbewerbspolitik und Kartellrecht. Eine interdisziplinäre Einführung. Stuttgart: Lucius

Schweitzer H. and Mestmäcker. (2014). Europäische Wettbewerbsrecht, 3.Auflage. München: CH.Beck.

Shiau D. and Chen E. (2014). ASEAN Developments in Merger Control. Journal of European Competition Law and Practice, 5(3): 149-157.

Silalahi, U. (2012). Accelerating the Development of ASEAN Competition Culture, Law Review, XII (2): 241-254.

Silalahi, U. (2017). "The Harmonization of Competition Laws towards the ASEAN Economic Integration," Journal of East Asia and International Law, 10 (1): 117-137.

Sivalingam, G. (2005). Competition Policy in ASEAN Singapore. Singapore: Thomson Learning Ltd.

Smith, M.W., \& Jones, D.M. (2007). Making Process, Not Progress: ASEAN and the Evolving East Asian Regional Order. International Security. 32 (1).

Stephan A. (2011). The Role of Competition Policy in Promoting the ASEAN Economic Community, ESRC Centre for Competition Policy University of East Anglia. Paper presented in the ASEAN Competition Conference, Bali, December 2011.

Tarullo, D.K. (1999). Competition Policy for Global Markets, Journal of International Economic Law (2):445-455

Terhechte, J.P. (2009). International Competition Enforcement Law Between Cooperation and Convergence - Mapping a New Field for Global Administrative Law Oxford: The University of Oxford Centre for Competition Law and Policy Working Paper CCLP-L26.

Terhechte, J.P. (2011). International Competition Enforcement Law Between Cooperation and Convergence. Berlin: Springer.

Thanadsillapakul, L. (2004). The Harmonization of ASEAN Competition Laws and Policy from an Economic Integration Perspective. Uniform Law Review (2004):749770

Thanadsillapakul, L. (2016). Framework Agreement on the ASEAN Investment Area (AIA), Thailand Law Forum (2016)

The Organisation for Economic Co-operation and Development-OECD Secretariat. (2008). OECD Guidelines for Multinational Enterprises. Paris.

The World Bank. (2005). Regional Trade and Preferential Trading Agreements: A Global Perspective in The Global Economic Prospect Washington D.C. 
United Nations Conference on Trade and Development (UNCTAD). (1997). World Investment Report 1997: Transnational Corporations, Market Structure and

Van den Bossche, P. (2010). The Law and Policy of the World Trade Organization: Text, Cases and Materials, 2nd Edition, Cambridge: CUP.

Woolcock, S. (2003). International Competition Policy and the World Trade Organization. Paper for the LSE Commonwealth Business Council Trade Forum in South Africa.

WTO Secretariat. (2011). A Handbook on the GATS Agreement. Geneva: WTO Secretariat. 